\title{
POSTAPOPLECTIC DEVELOPMENT OF BRUNS'S NYSTAGMUS IN TWO BROTHERS
}

By

S. FUJISAKI, S. SAKAI, T. MOTIZUKI AND T. MATSUNAGA

From the E.N.T. Department, Osaka University School of Medicine (Director: Prof. T. Hasegawa)

Postapoplectic development of unilateral facial nerve palsy and paralysis of the contralateral upper and lower extremities were observed in two, 47 years old and 50 years-old brothers.

Angiographically, the diagnosis of thrombus formation in either posterior inferior or anterior inferior cerebellar artery was established.

Otologically examined, both of them were noted to have Bruns's nystagmus, the larger nystagmus of which was directed to the side of facial nerve palsy.

It is interesting that Bruns's nystagmus, which had been generally considered to be characteristic to cerebellopontine angle tumor, occured following an attack of cerebellar apoplexy.

We have recommended postural nystagmus test for the purpose of early discovery and differential diagnosis of circulatory disturbances in brain.

The importance of Bruns's nystagmus is to be emphasized for the same purpose.

\section{兄弟に現われた脳卒中後のBruns 様眼振}

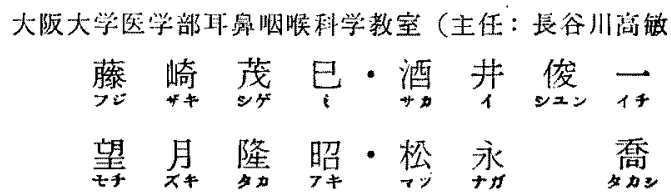

\section{緒 言}

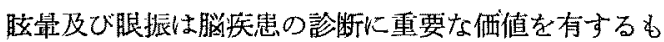
のであるが，殊に特殊な眼振は，その眼振のみで脳の障 害部位を診断し得る場合さえある。

この特殊な腿振の 1 つに Bruns 1) の腿振がある，こ れは Bruns (1908) が小脸橋的埂湯の患者に見出したも のである. 即ら正常頭位にて菂者の朖前約 $30 \mathrm{~cm}$ のと ころにて検者の指先を見つめさし，これを左右に動か し，右方文仕左方を疑視世しめるとき凝視方向に向う腿 振が現れこれが左右大小を示するのである。

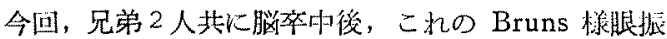
と顔面神絟麻㾇を認めたのでこつに報皆する。

症例!大○金○50才。

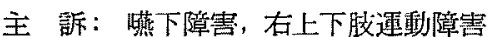

現病歴：昭和 35 年 4 月 15 日夕刻飲酒後急に眩鼠を 訴之冷汗をかき意識や〉不明眿となるも完全な消失はな
かつたそとの日より攃下障害，右上下抆の運動障害，左 半身の温覚痛覚脱失をきたした，意識不明嘹の時に両眼 共左へ偏位していたことがあつた，発作持の血圧は最高 血圧が約 $200 \mathrm{mmHg}$ と云われた. 発作後頭位を変えると自分の体が迴る様な眩最を感 じ，同時に榎声あり，咽頭部に常時痰がたまる。 既往症： 5 年前糖尿病 家族歴：母は69 才の時脳卒中にて死亡，本人は 4 男 (符 1 洨)，弟 (症例 II) は6 男.

初晾：炤和 36 年 6 月 16 日（発作後 1 年 2 力月）

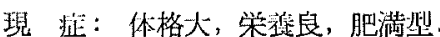

一般娭盗（第2 婊）

神経科学的所見（第 3 表）

耳率科学的所見

一般检查は（第 4,5表）に見られる通りである。

自発眼振：正常頭位にて右一问眼振が見られ，右 
第 1 表

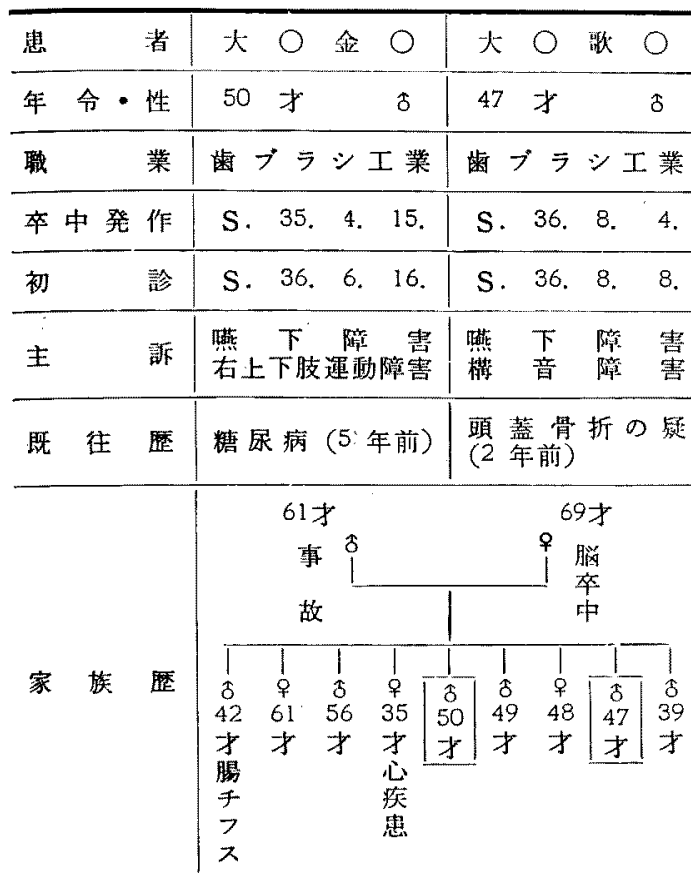

第 2 表

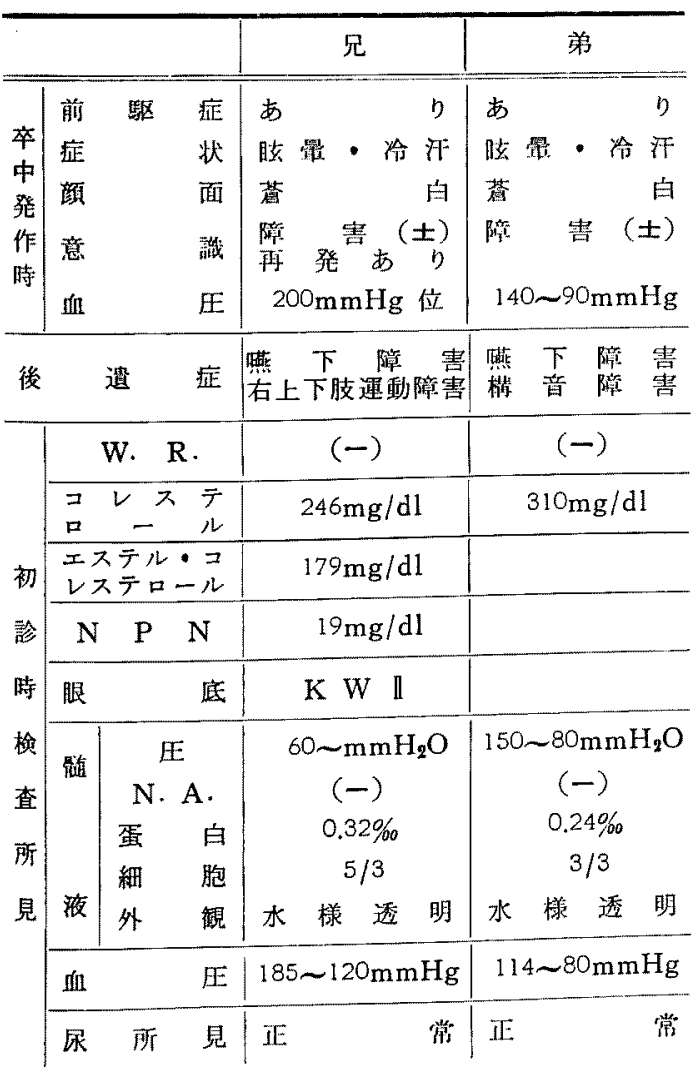

第3 表剂経学的听見

\begin{tabular}{|c|c|c|c|}
\hline & & & 弟 \\
\hline 睡 & $孔$ & 古縮瞕(柽) & 左縮瞕(軽) \\
\hline 角 & 膜层 & 右 & 雨 正 裳 \\
\hline 腿 & 裂 & 右や夕狄 & 左中s狄 \\
\hline 顇 & 面 知 & 在や1鈍 & 网 亚賞 \\
\hline 味 & 覚 & 闭 正 常 & 两 正 常 \\
\hline 胸 & 鎖 乳 突 筋 & 右や〉マヒ & 两 正 常 \\
\hline $\begin{array}{l}\text { 梁 } \\
\text { 部 } \\
\text { 反 } \\
\text { 射 }\end{array}$ & $\begin{array}{lll}\text { 腕 } & \text { 反 } & \text { 射 } \\
\mathrm{P} & \mathrm{S} & \mathrm{R} \\
\mathrm{A} & \mathrm{S} & \mathrm{R}\end{array}$ & $\begin{array}{l}\text { 両正常 } \\
\text { 右や> 弱 } \\
\text { 耐や>弱 }\end{array}$ & $\begin{array}{lll}\text { 両 } & \text { 正 } & \text { 常 } \\
\text { 両 } & \text { 正 } & \text { 常 } \\
\text { 両 } & \text { 正 } & \text { 常 }\end{array}$ \\
\hline $\begin{array}{l}\text { 裴面 } \\
\text { 区射 }\end{array}$ & $\begin{array}{llll}\text { 腹 } & \text { 壁 } & \text { 射 } \\
\text { 提 } & \text { 枯 } & \text { 反 } & \text { 射 } \\
\end{array}$ & $\begin{array}{l}\text { 两正 常 } \\
\text { 右 消 失 }\end{array}$ & 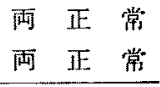 \\
\hline $\begin{array}{l}\text { 病 } \\
\text { 的 } \\
\text { 晠 } \\
\text { 射 }\end{array}$ & $\begin{array}{l}\text { ベンスキ } \\
\text { チアドック } \\
\text { オッペンハイム }\end{array}$ & $\begin{array}{lll}\text { 雨 な } & \text { な } \\
\text { 雨 } & \text { な } \\
\text { 呵 な } & \text { し }\end{array}$ & $\begin{array}{lll}\text { 両 } & \text { な } & \text { 两 } \\
\text { な } & \text { L } \\
\text { 两 } & \text { よ }\end{array}$ \\
\hline $\begin{array}{l}\text { 智 } \\
\text { 賞 }\end{array}$ & $\begin{array}{l}\text { 賞 } \\
\text { 觉 }\end{array}$ & $\begin{array}{l}\text { 鋰 } \\
\text { 鈍 }\end{array}$ & 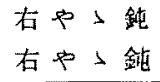 \\
\hline \multicolumn{2}{|c|}{ アデイアドュキネーゼ } & $(t)$ & 雨 な \\
\hline 鳎 & 試 & 排 & 两 IE 常 \\
\hline 企 & 图性 振 顸 & $( \pm)$ & 网就 \\
\hline
\end{tabular}

第4 表 闵科的所見

\begin{tabular}{|c|c|c|}
\hline & 兄 & 弟 \\
\hline 鼓 & 常 & 洙 \\
\hline 奥 粘 膜 & 乾 & 焰 \\
\hline 㜞口薀 & 右 マ 七（軽度） & 左 $、$ 七 (怪度) \\
\hline 舌 $\left|\begin{array}{ll}\text { 連 } & \text { 動 } \\
\text { 基 } & \text { 樎 }\end{array}\right|$ & 正 $(-){ }^{\text {常 }}$ & (-) \\
\hline 葴下反射 & 久 & 欠 \\
\hline 上䝿面箈 & 正 & 正 \\
\hline 下頙面筋 & 至マヒ (柽 应) & 左マと (怪 度) \\
\hline 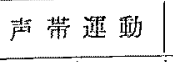 & 右マヒ(正中位固空) & $\mathrm{IE}$ \\
\hline \begin{tabular}{l|l|} 
自発 & 正中視 \\
腿振 & 僛方視 \\
\end{tabular} & $\begin{array}{l}\text { 右 } \\
\text { 右 } \leftarrow \text { 左 } \\
\end{array}$ & $\begin{array}{l}\text { 右 } \\
\text { 右 } \\
\end{array}$ \\
\hline 側頭位恨振 & $\begin{array}{c}\mathrm{R} \\
\mathrm{S} \cdot \mathrm{L} \cdot \downarrow\end{array} \downarrow \uparrow \begin{array}{c}\mathrm{L} \\
\mathrm{S} \cdot \mathrm{L} .\end{array}$ & $\mathrm{R} \cdot \mathrm{L} \cdot \downarrow<\downarrow \mathrm{s} \cdot \mathrm{L}$. \\
\hline 步行检查 & 左 & 能 \\
\hline 起立検 查 & $\hat{n}$ & 能 \\
\hline 指示㮝査 & 不 & 右 手 左 \\
\hline
\end{tabular}


方を注視させると右向きの大きなゆつくりした眼振が， 左方を注視させると左向きの小さな速かな眼振（Bruns 様の眼振) が見られた。

側頭位眼振：両側頭位にても同様の Bruns 様腿振 が認められたが，左側頭位の眼振が右側頭位のとれより

\section{第 5 表}

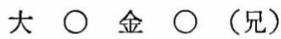

心 電 図：異常なし

脳波：注よ゙正常 過呼吸にて徐波出現

聴力検查:

D L.( ( )

脳血管撮影:

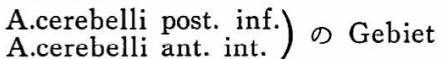

の Thrombose 思わせる

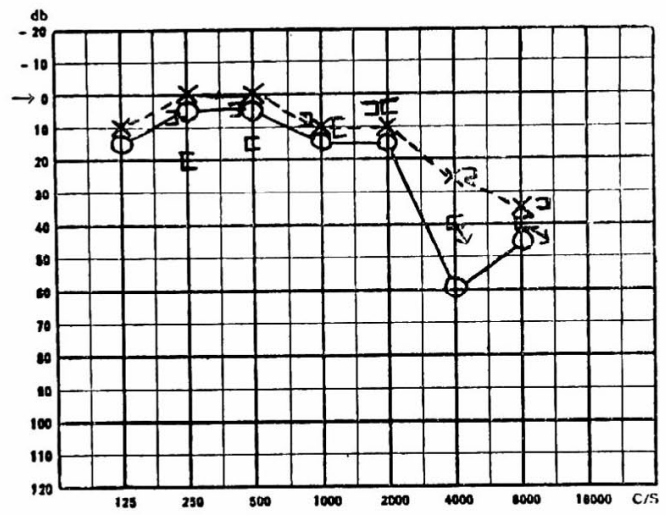

振巾は大であつた.

回䩓刺㦸検查（第 5 表）

振子様回転検査：

右へ向ら眼振が著明であつた。

温熱刺軲検査： $30^{\circ} \mathrm{C}, 20 \mathrm{cc}, 44^{\circ} \mathrm{C}, 20 \mathrm{cc}$ にて反応な ᄂ.

脳血管レントゲン撮影：(第 1 図)。

右の A. vertebralis より造影剂を注入，右の A. basilaris が狭小となつてわずかに造影された．

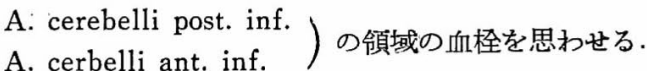
症例 II 大○歌○ 47 才。（症例 I の弟）

主 訴: 嶼下障害, 構音障害.

現病歴：昭和 36 年 8 月 4 日午前中仕事が拙劣となり

第具1 図

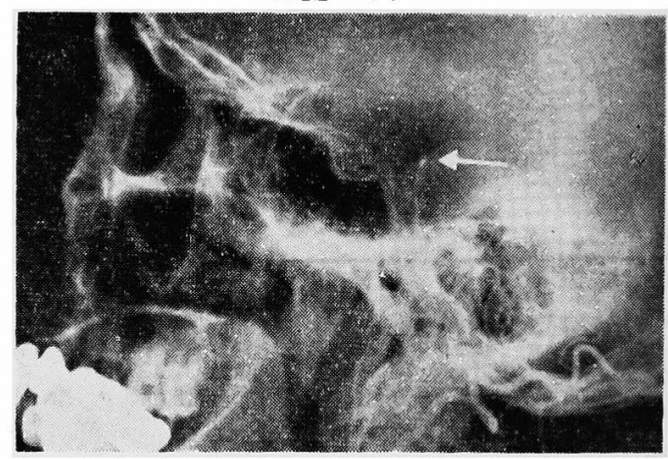

1. 迴転刺戟検查（佪枟後腿振）;

\begin{tabular}{|c|c|c|c|c|c|c|c|c|c|c|}
\hline \multirow{2}{*}{ 方 } & & \multirow{2}{*}{ 向 } & \multirow{2}{*}{ 速 } & \multirow{2}{*}{ 度 } & \multirow{2}{*}{ 持続時間 } & \multirow{2}{*}{ 振 限 数 } & \multirow{2}{*}{ 振 } & \multicolumn{3}{|c|}{ 骮伴 現 象 } \\
\hline & & & & & & & & 眩 暈 & 悪 心 & ソノ他 \\
\hline 左 & 回 & 転 & 51 & & $28^{\prime \prime}$ & $20 / 5^{\prime \prime}$ & 中〜小 & $(t)$ & $(-)$ & \\
\hline 右 & 回 & 檕 & & 10秒 & $14 \prime \prime$ & $5 / 5 \prime \prime$ & 中 & $(-)$ & $(-)$ & \\
\hline
\end{tabular}

2. 温熟刺戟検査;

\begin{tabular}{|c|c|c|c|c|c|c|c|c|c|c|}
\hline 水 温 & 水 量 & 側 & 洁伏時間 & 持続時間 & 限 振 数 & 振 & 幅 & 眩 最 & 悪 心 & ソノ他 \\
\hline \multirow{2}{*}{$30^{\circ} \mathrm{C}$} & \multirow{2}{*}{$300 \mathrm{cc}$} & $\mathrm{R}$ & $50 \prime \prime$ & $92 \prime \prime$ & $8 / 5 \prime \prime$ & & & $(-)$ & $(-)$ & \\
\hline & & $\mathrm{L}$ & $58 \prime \prime$ & $65^{\prime \prime}$ & $4 / 5 / \prime$ & & & $(-)$ & $(-)$ & \\
\hline $44^{\circ} \mathrm{C}$ & $300 \mathrm{cc}$ & $\begin{array}{l}\mathrm{R} \\
\mathrm{L}\end{array}$ & $\begin{array}{l}\text { なし } \\
48 / \prime\end{array}$ & $\begin{array}{l}\text { なし } \\
56 " 1\end{array}$ & $\begin{array}{l}\text { なし } \\
8 / 5 \prime \prime\end{array}$ & & & $(-)$ & -) & \\
\hline
\end{tabular}




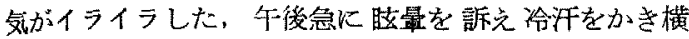
卧，顔面荅白となる，䄪 10 分間意識不明瞭となるる完 全には消失せず，化の後すぐ悲下障害を訴え舌がるつれ 構音障㫪もきたした，発作侍血圧 140 -90 $\mathrm{mmHg}$ と云 われた。

既往庭：昭和 34 年 6 月交通事故以て頭蓋底骨折の䈣 ありと云われたが，その後異常はなかつた。

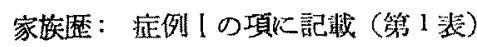

初診：昭和 36 年 8 月 8 日 (発作後 4 日目)

琴 症：体格大，栄䬭良，肥満型

一般検查 (第 2 表)

神経科学的所見 (第 3 表)

聴力検查:

C. fis4. 其闻側整安短樎

Rinne 阿側 (十)

Weber 正中

步行検査並びに転到掺盉は不能（安静を要したため）

(第4 表)

指示検查：右手が左へ偏倚した。

自発眼振：正常頭位にて右入向引眼振が見られ，右 方を注視させると右へ向ら大きな腿振が，左方を注視さ せると左向きの小さな速かな眼振 (Bruns 様の腿振) が 見られたー

側頭位眼振：雨側頭位にても阔様の Bruns 様の腿振 が認められたが，左側顠位の眼振が右側頭位の場合上り 振巾は大であつた。

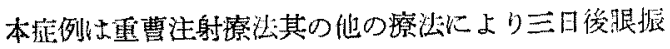
も消失退院したため充分の惨查は行えなかつたがレ緣像 以症例 I（兄）之同様の部位に血柽像を認めた。

\section{総括及ひ考按}

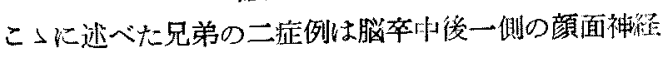
と上下肢の䐐序を認め延䪔の高さで病装の起つたもの で, 精密桧查によつて, A. cerebelli post. inf. か. A. cerebelli ant. inf, の領域の血栓々馀断されたものであ る. 然力も兄弟とも同侧の顔面神释麻瘦とその反对侧に 向ら主腿振をもつ Bruns 様の眼振が見られた。

このBruns の腿振は1908 年 Bruns 1) が小脳橋解腫

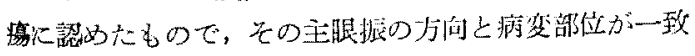
すると述べている.

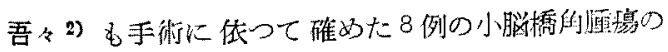
Bruns の眼振の方向之病㚆部位の関係愔 Bruns の説と 全く符合していた，又其の他後頭部外賃 ${ }^{3)}$ の1例に Bruns の眼振老認めたが，脳の他の部の障彗にはこの
眼振は全く認められなかつた。

さて脳卒中患者では Bruns の眼振は見られないだろ うか，従来この種の研究はあまりない様である、私共 4) は2 5 例の脳卒中患者の中 20 例炕眼振(自発腿振之側頭 位腿振）を認め大が，其の中 Bruns 様の眼振を認めた もの5 例で，脳卒中症の中には比較的高率に橋部文は延 龍の障害を起す事を示している。しかしとの場合障害の 部位は橋部又は延嘴であるが，塆害側はＢruns 眼振の 主眼振の方向と一致しない例のある事が誌められた。

Grahe 5) は橋部及び延㩆の 病変部が頭側であれば眼 振は病㑯向い，中央部では煡側に向い，ダイテルス核 の吻貸では垂值性眼振が現わ机ると記している。

この Grahe の説を参照して Bruns の眼振と絾障害 部位を検討して見ると，小脳橋解腫場はとの発生部位が

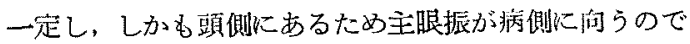
あるが，脳卒中はとの発生部位が一定しないため，頭側 のものは主眼振は病側们向らが，中央部のものは健側に 向うのではないかと考党られる。

之はい之，兄弟 2 人に同し脳血管に血恎が認められた

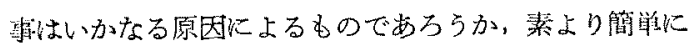

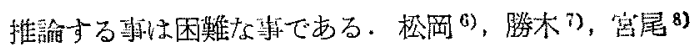

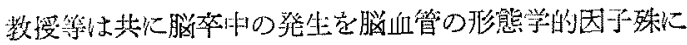

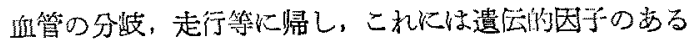
然を強調している。

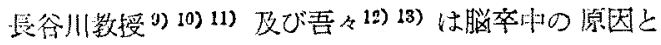

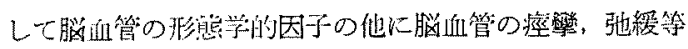

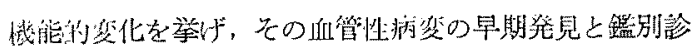

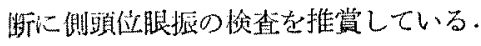

今回は更に Bruns 腿振の佮睢の必要性を誌めた。

\section{結論}

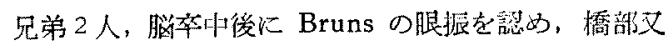
は延道に病变のある事を指適し，レ楾娭直に上つて確認 した症例である.從来この Bruns の腿振は小脳橋的遇 摬に見られるものとされていたが，今回脳卒中以認るら れた。

\section{文献}

1) Bruns, L.. Die Geschwülste des Nervensystems,

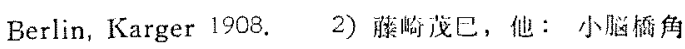

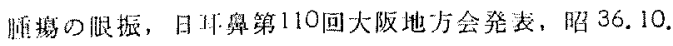

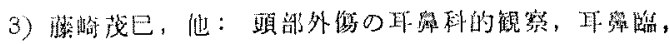

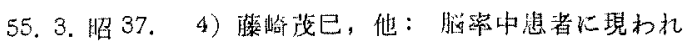

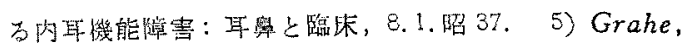
K.: Hirn und Ohr. Georg Thime Verlag Leipzig 
1932. 6) 松岡茂：高血压と勘脈病変, 最新医学, 15.6.1454. 昭 35, 脳血管性障害の局所案因, 第12回日 本体質学会発表, 昭 36,12.7) 勝木间孯之助：卒中 症と体質，特に血管病变を中心として，第12回日本体質 学会発表, 炤 36.12.8）宮星定信：卒中体質につW $\tau$, 第12回日本体質学会発表, 昭 36.12.99) Haseg. awa, T.: Pfléger's Arch. 229: 2, 205 225, 1931. 10) Hasegawa, T.: Z. Hals-usw. Heil. 41: 168 172, 1939. 11) Hasegawa, T.: Acta Med. Nag*

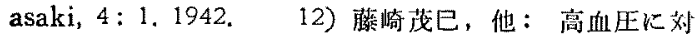

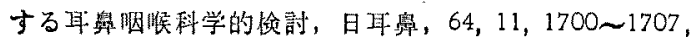

昭 36. 13) 侧顕位眼振检查によつて発見された脳動脈 硬化症例，最新医学，16.12,3238～3242，昭 36.

本馀交の要旨は第12回日本体質学会（昭36年 12 月）「体質と卒中」シンポジフムにて咉画と

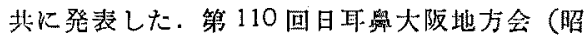
36 年10月）に発裴した。

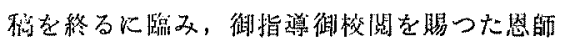
長谷川高酷教㖟に梁く感謝致します。

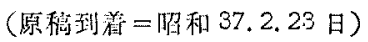

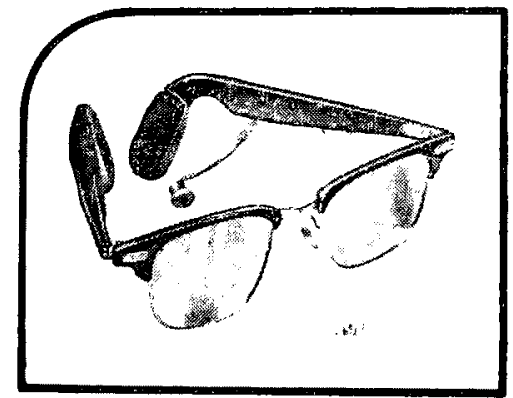

米・英・独など補聴器の先進国から最新の めがね補聴器・コードなし補聴器等いろい ろ珍らしい補聴器を直輸入して取揃え難聴 者各位の御利用に供しています。

\section{補聴器の御用はどうぞ日本補聴器へ}

一党 業 品 目

英・米・独製各種新型補聴器 補聴器用米国製水銀”電池各種 内 外補 聴器修理 改造 補聴器輸入販壳專門の店 日本補聴器販売株式会神 